\title{
REGULATING COMPENSATION FOR THE PROTECTION OF TRADITIONAL FISHERMEN AFFECTED BY POLLUTION IN INDONESIA*
}

\author{
Suhaidi Suhaidi** \\ Sutiarnoto Sutiarnoto*** \\ Syaiful Azam**** \\ Rosmalinda Rosmalinda*****
}

\begin{abstract}
Indonesia is known as a maritime state which is associated with marine and fisheries activities. The existence of a harbor, such as the Port of Belawan in Medan City, often causes conflicts in the issue of marine fisheries, especially related to sea pollution. This article investigates the implementation of compensation when traditional fishermen are affected by environmental pollution, especially tankers, its opportunities and challenges in the Indonesian legal context. This study employed a normative and empirical approach, covering the study sites of North Sumatra and Riau Islands Province, which share the border with the Malacca Strait. To date, there are no rules regarding compensation for fishermen, however, there are some embryonic mode such as the existence of experienced human resources from the Environmental Agency of Riau Islands Province in the implementation of compensation for traditional fishermen affected by pollution of the marine environment. This study encourages the local government (i.e., the
\end{abstract}

* This paper is adapted from a paper presented at the International Conference on Law, Governance and Islamic Society-ICOLGIS-2019 titled "Compensation Regulation for Traditional Fisheries Affected Pollution, Challenges and Opportunities".

** Lecture of Faculty of Law, Universitas Sumatera Utara, Medan, Indonesia. Email: suhaidi@usu.ac.id.

*** Lecture of Faculty of Law, Universitas Sumatera Utara, Medan, Indonesia. Email: sutiarnoto@usu.ac.id.

**** Lecture of Faculty of Law, Universitas Sumatera Utara, Medan, Indonesia. Email: syaiful@usu.ac.id.

*****Lecture of Faculty of Law, Universitas Sumatera Utara, Medan, Indonesia. Email: rosmalinda@usu.ac.id. 
provincial government) to give more attention related to the compensation for traditional fishermen who are affected by pollution of the marine environment in the form of Regional Regulations or other policies.

Keywords: compensation, traditional fisheries, opportunities, challenges.

\title{
PENENTUAN PAMPASAN UNTUK MELINDUNGI NELAYAN TRADISIONAL DI INDONESIA YANG TERLIBAT DENGAN PENCEMARAN ALAM SEKITAR
}

\begin{abstract}
ABSTRAK
Indonesia terkenal sebagai negara maritim yang terkait dengan kegiatan laut dan perikanan. Kewujudan pelabuhan, seperti Pelabuhan Belawan di Kota Medan, sering menimbulkan konflik dalam isu perikanan laut, terutamanya apabila timbul permasalahan pencemaran laut. Makalah ini menyelidiki pelaksanaan pampasan ketika nelayan tradisional terkesan oleh pencemaran alam sekitar, terutamanya pencemaran dari kapal tangki. Makalah ini turut melihat peluang dan kekangan dalam konteks undang-undang Indonesia. Kajian ini menggunakan pendekatan normatif dan empirikal yang meliputi lokasi kajian di Sumatera Utara dan Provinsi Kepulauan Riau, yang berbatasan dengan Selat Melaka. Hingga kini, tidak ada peraturan mengenai pampasan bagi nelayan, namun, ada beberapa punca seperti adanya sumber manusia yang berpengalaman dari Badan Lingkungan Hidup di Kepulauan Riau dalam melaksanakan pampasan bagi nelayan tradisional yang terkesan oleh pencemaran persekitaran laut. Kajian ini mencadangkan ketua daerah (iaitu, pemerintah provinsi) untuk memberikan perhatian lebih terperinci terhadap pampasan bagi nelayan tradisional yang terkesan oleh pencemaran persekitaran laut dalam bentuk Peraturan Daerah.
\end{abstract}

Kata kunci: pampasan, nelayan tradisional, kesan pencemaran laut, cabaran pelaksanaan undang-undang alam sekitar.

\section{INTRODUCTION}

The marine environment is a source of natural wealth, and an important means of connecting people aside from providing much needed recreational places. It is very important to ensure the sustainability of the ocean through the protection of the marine environment from 
pollution originating from ships. This will enable the utilization of its resources to be enjoyed by fisherman and future generations. ${ }^{1}$ Efforts to prevent pollution of the marine environment have been carried out by the international community. The International Maritime Organization (IMO), for example, through various efforts, has included international provisions on the prevention of marine pollution and provisions regarding the prevention of pollution to the marine environment with the responsibility placed on the perpetrators to pay compensation. $^{2}$

For Indonesia, as an archipelagic country, the inception of the United Nations Convention on the Law of the Sea (UNCLOS) 1982 affirms its status. The total area of Indonesia has increased to 8,193,163 $\mathrm{km}^{2}$, consisting of 2,027,087 $\mathrm{km}^{2}$ of land and $6,166,163 \mathrm{~km} 2$ of seas. The total area of the Indonesian sea can be broken down into 0.3 million $\mathrm{km}^{2}$ of territorial sea, 2.8 million $\mathrm{km}^{2}$ of archipelago waters, and $2.7 \mathrm{~km}^{2}$ of Indonesia's Exclusive Economic Zone. North Sumatra and the Riau Islands Province, the locations of the present study, are certainly affected by the enactment of UNCLOS 1982.

The North Sumatra Coast has a Coastal Length of $1300 \mathrm{~km}$ consisting of $545 \mathrm{~km}$ of East Coast Length and $375 \mathrm{~km}$ of West Coast Length with fisheries potential in the Malacca Strait of 276,030 tons per year. Having this potential, this area is the subject of various studies relating to the Malacca Strait Policy. One reason that makes the North Sumatra coast an exceptional object to discuss is the presence of a new port namely the Port of Kuala Tanjung in the Batu Bara district. The existence of this port has been mentioned in the North Sumatra Province Regional Regulation No. 2 of 2017 concerning the Spatial Planning for the North Sumatra Province in 2017-2037. Kuala Tanjung Multi-Purpose Terminal (KMTM), or the Port of Kuala Tanjung, North Sumatra, has begun its operation since December 2018. This port is prepared to become an International HUB port, which is an area of activity with the function of being a hub for goods transhipment and a gateway for the economic and manufacturing sectors through the

1 Mochtar Kusumaatmadja, Perlindungan Dan Pelestarian Lingkungan Laut Dilihat Dari Sudut Hukum Internasional, Regional, Dan Nasional, (Jakarta: Sinar Grafika Dan Pusat Studi Wawasan Nusantara., 1992), 30.

2 Suhaidi Sutiarnoto and Azam, "Legal Protection for North Sumatra East Coast Fishermen in the Indemnification of Malacca Strait Oil Spill," Journal of Legal, Ethical and Regulatory Issues 22, no. 2, (2019): 1-7. 
connection of inland transport systems and ship feeder systems, along with six other ports in Indonesia, namely: Tanjung Priok Port in Jakarta, Tanjung Perak in Surabaya, Kijing in Pontianak, Bitung in North Sulawesi, Makassar Port and Sorong Port. ${ }^{3}$

This is an intriguing issue to be discussed, especially when it comes to the geographical location of the study. In this regard, it is similar to the case of the Riau Islands Province, which is also the location of the current study. The total area of the Riau Islands in the form of land is $8,201.72 \mathrm{Km} 2$, which consists of 1,796 islands. Based on the Minister of Home Affairs Regulation No. 56 of 2015, the total land area of each regency/city is detailed as follows: (1) Karimun $\left(912.75 \mathrm{~km}^{2}\right),(2)$ Bintan $\left(1,318,21 \mathrm{~km}^{2}\right)$, (3) Natuna $\left(2,009.04 \mathrm{~km}^{2}\right),(4)$ Lingga $\left(2,266.77 \mathrm{~km}^{2}\right)$, (5) Anambas Islands $\left(590.14 \mathrm{~km}^{2}\right)$, (6) Batam City $\left(960.25 \mathrm{~km}^{2}\right)$ and (7) Tanjung Pinang City $\left(144.56 \mathrm{~km}^{2}\right)$. There are 385 inhabited islands, 19 of which are the major islands that directly border with other countries.

Both North Sumatera and the Riau Islands have marine territories located in the Malacca Strait, which is closely related to the One Belt One Road (OBOR) policy, a policy of the People's Republic of China in foreign and economic strategy. The term was popular in 2013 to discuss the concept of 'Silk Road Economic Belt' and the '21st-Century Maritime Silk Road'. These concepts were used by China to link Europe to China through countries across Eurasia and the Indian Ocean in the economic context. The concept is improved gradually including the initiative to link China to Africa and Oceania in 2015. ${ }^{4}$ The fact that Indonesia is an archipelagic state gives it an important role to implement the OBOR policy due to its geographic position, such as North Sumatera and Riau Islands in the Malacca Strait. Furthermore, Indonesian roles in the implementation of OBOR

3 Siahaan, Wilmar Jonris, et al, "Pelabuhan Kuala Tanjung Sebagai Pelabuhan Hub Internasional Ditinjau dari Aspek Jaringan Pelayanan," Warta Penelitian Perhubungan 31, no. 2, (2019): 83-92.

4 Geoff Wade, "China's 'One Belt, One Road' initiative," Parlieament of Australia, accessed January 1, 2017, https://www.aph.gov.au/About_Parliament/Parliamentary_Departments/ Parliamentary_Library/pubs/BriefingBook45p/ChinasRoad. 
Policy are supported by the vision of Indonesia as the world's maritime axis. ${ }^{5}$

The diversity of related institutions ${ }^{6}$ that need to be studied together so that later can be a form of mutual support for the handling of pollution and not the omission if there are cases of marine pollution. When there is a condition of environmental damage, it will be a threat to living things, including humans, even though environmental damage is directly due to human behavior to utilize environmental goods and services in order to meet the needs of human life. Constitutionally there are legal norms that protect the public to get a good and healthy environment and this must be done by the state. This is stated in the 1945 Constitution Article 28 (h).

Until now, related to the study of environmental losses, guided by Law Number 32 of 2009, while related to the application of fisheries compensation affected by oil spill pollution in sea waters, one of which can be guided by Law Number 7 of 2016. The role of the regional government became dominant when implementing this regulation.

The considerations of Law Number 7 of 2016, stated that one of the responsibilities of the state is to protect and advance public welfare; and one of the efforts made to make it happen by organizing Protection, Empowerment of Fishermen, Fish Hatchers, and Salt Farmers in a planned, directed, and sustainable manner for fisheries businesses. Fisheries business actors are very dependent on fish resources, environmental conditions, facilities and infrastructure, business certainty, access to capital, science, technology, and information.

5 Suhaidi, Rosmalinda, Alhayyan, R., and Tarigan, V. C, "The Readiness of North Sumatra Regional Government in The Field of Marine Environment to Realize the World's Maritime Axis on East Coast," International Journal of Civil Engineering and Technology (IJCIET) 9, no. 10 (2018): 1695-1705.

6 Several agencies are related to handling the impact of sea pollution, which the main actors of this fishery business according to their duties and functions is the responsibility of the Ministry of Maritime Affairs and Fisheries (KKP). Other related agencies to settle pollution namely the Ministry of Environment and Forestry (KLHK), the Ministry of Maritime Affairs and Fisheries (KKP), the Ministry of Home Affairs (Ministry of Home Affairs), and the Ministry of Energy and Human Resources (Ministry of ESDM). 
As part of the subject of international law and internationally socialized countries, Indonesia has ratified several Conventions relating to the marine environment such as;

1. The 1982 Law of the Sea Law with Law No. 17 of 1985.

2. International Convention on Civil Liability for Oil Pollution Damage, 1969 (CLC 1969) by Presidential Decree (Keppres/Keputusan Presiden) RI No. 18 of 1978, and

3. International Convention on the Establishment of an International Fund for Compensation of 1971 Oil Pollution Damage with Presidential Decree No. 19 of 1978.

However, Keppres No. 19 of 1978 has been removed by Presidential Decree No. 41 of 1998 based on the reason that the membership of the Government of Indonesia at the Convention has been burdened. Therefore, membership in the International Convention on Civil Liability for Oil Pollution Damage, 1969 (CLC 1969) through Presidential Decree RI No. 18 of 1978 is considered sufficient to be able to provide guarantees of compensation funds for pollution of the marine environment sourced from marine oil spills. ${ }^{7}$ There is an interesting point on view of the compensation regime applied by a country like Indonesia. The maximum compensation provided is for the protection of the marine environment due to oil pollution by tankers. The fishermen, however, whose main source of income is from the sea, only receive the disadvantages of marine pollution. ${ }^{8}$

It is a fact that traditional fishermen who are affected by pollution of the marine environment caused by tankers are not mentioned in the international legal arrangements regarding compensation for marine pollution caused by tankers as stated in CLC 1969. This international instrument focuses on Compensation which

7 Suhaidi, Sutiarnoto, and Azam, S., "Legal Protection for North Sumatra East Coast Fishermen in the Indemnification of Malacca Strait Oil Spill," Journal of Legal, Ethical and Regulatory 22, no. 2 (2019): 1-7.

8 Purwendah and Elly Kristiani, "Penerapan Regime Tanggung Jawab dan Kompensasi Ganti Rugi Pencemaran Minyak oleh Kapal Tanker di Indonesia," Jurnal Komunikasi Hukum (JKH) (2016): 22. 
must be paid for pollution of the sea or the environment. This condition certainly requires problem solving in the context of compensation for fishermen whose main source of income is from the sea. The traditional fishermen are subjects not currently being considered as the subject of loss. They should be considered as subjects of loss due to their main income being fishing and are severely affected when the sea and the environment are polluted. ${ }^{9}$ This paper investigates the extent to which the traditional fishermen have compensation as a form of protection for them due to the polluted sea and environment.

\section{METHODOLOGY}

This research applied the normative empirical methodology. Some laws in Indonesia were reviewed to figure out the availability of regulation concerning compensation for traditional fishermen. Furthermore, some informants were recruited from different institutions or parties namely, local government both in North Sumatera and Riau Islands Provinces and also the community including the fishing community and its organizations namely Himpunan Nelayan Seluruh Indonesia (HNSI)/Union of Fishermen in Indonesia. The informants were interviewed using an interview guide. At the end of the research, a dissemination session is participated by the representative of the Local government of North Sumatera Province and the fishermen organization. Meanwhile, due to distance, the informants from Riau Islands Province were absent in the session.

\section{RESULT AND DISCUSSION}

The division of powers prevailed in Indonesia in the relationship between the Central Government and Local governments in the context of a vertical understanding as affirmed in Article 18 paragraph (1) of the 1945 Constitution of the Republic of Indonesia. This article states as follows:

9 Kadam, Deepa, Sandeep Bhanot, and Devayani Savant. "Awareness of marine pollution in fishermen communities in Mumbai." Current perspectives in sustainable environment management (2017): 304-311. 
The Unitary State of the Republic of Indonesia is divided into provincial regions, and these provincial regions are divided of the Regency and City, which each Province, Regency, and City have a local government which is regulated by law.

Furthermore, in terms of authority, the relationship between the Center and the Regions is regulated in the law by taking into account the specificity and diversity of the region (Article 18 A paragraph (1) of the 1945 Constitution of the Republic of Indonesia). ${ }^{10}$ According to Chapter I in General Provisions of Law No. 23 of 2014, the local government is the head of the region as an element of the organizer of the local government that leads the implementation of government affairs by the authority of the autonomous regions. Moreover, the local government is in charge of government affairs by the local government and the Regional Representative Council according to the principle of autonomy and deconcentration by the principle of broadest autonomy in the system and the principles of the Republic of Indonesia as referred to in the 1945 Constitution of the Republic of Indonesia.

The enactment of Law No. 23 of 2014 made a change in the authority of provincial sea management, which was originally from 412 miles to 0-12 miles. Today, there is a regulation on water management previously carried out by the Regency or City Government. Now, this is taken over by the Provincial Government, including the sea zoning authority which used to be 4-12 miles, and 012 miles. Previously, 0-4 miles of marine zoning was under the authority of the Regency or City Government. In the case of the division of affairs between the Central Government, the Provincial Region and the Regency or City Region, specifically in the maritime and fisheries sector which is taken over by the Central Government and the Provincial Region. An assumption that the granting of authority only to the Provincial Government of the Region is not relevant with the purpose of granting the broadest possible autonomy to the Regions directed to accelerate the realization of people's welfare through improved services, empowerment, and community participation. Moreover, an important substance of regional autonomy is the delegation of authority from the Center to the Regions politically and

10 See article 18 A paragraph (1) of the 1945 Constitution of the Republic of Indonesia. 
economically for development and economic growth equitable in the Region.

The condition and situation of Indonesia as an archipelago offers Indonesia challenges and opportunities in managing its seas. One challenge that is currently, which is the concern of this paper, the protection of the fishermen affected by pollution in the form of compensation. As mentioned above the opportunity related to compensation arrangements for fishermen is the existence of Law No. 32 of 2014 concerning Local governments such as North Sumatra Province and Riau Islands Province.

North Sumatra Province is located on the geographical coastline between 1 "-4" LU and 98 "-100" East BT, bordering to Aceh province to the north, while in the south it is bordered by West Sumatera and Riau Province. The western coast of North Sumatra meets the Indian Ocean while the east coast borders with the Straits of Malacca. As the East Coast of North Sumatra is $545 \mathrm{~km}$ in length, the sustainable potential (MSY) of several types of fish in its waters include Pelagic fish (126,500 tons/year), commercial fish $(110,000$ tons/year), coral fish (6,800 tons/year) and shrimp (20,000 tons/year). The east coast of North Sumatra consists of 7 (seven) regencies/cities, namely Langkat Regency, Medan City, Tanjung Balai City, Asahan Regency, Labuhan Batu Regency, Deli Serdang Regency, and Serdang Bedagai Regency. The total area of coastal districts in the eastern part of North Sumatra is $43,133.44 \mathrm{~km} 2$, which consists of 35 coastal districts subordinating 436 villages. On the east coast of North Sumatra Province, there are only 6 (six) small islands such as Berhala Island. This island, as the outer island of Indonesia, receives special treatment due to the security issue of Indonesia.

These regional conditions provide opportunities for the province of North Sumatera to explore the marine environment that benefits the community. Along with the existence of opportunities and the potentials to prosper by the fishermen, challenges arise in their management. North Sumatra, as a province directly facing the Malacca Strait, has the Belawan Port as one of the most important port in the Malacca Strait besides the Port of Klang (Port of Klang) in Malaysia. ${ }^{11}$

11 Siahaan, Wilmar Jonris, et al., "Pelabuhan Kuala Tanjung Sebagai Pelabuhan Hub Internasional Ditinjau dari Aspek Jaringan Pelayanan," Warta Penelitian Perhubungan (2019): 83-92. 
Nowadays, a new port has begun operating in the province of North Sumatra, namely Tanjung Gading Port in Batu Bara Regency. The existence of the two ports presents a challenge for the North Sumatra provincial government in its management, for example in the protection of fishermen when affected by sea pollution due to possible collisions of tankers navigating between the two ports.

\section{CHALLENGES IN THE IMPLEMENTATION OF COMPENSATION FOR TRADITIONAL FISHERMEN AFFECTED BY SEA POLLUTION}

The east coast of North Sumatra Province consists of 7 (seven) districts/cities, namely Langkat Regency, Medan City, Tanjung Balai City, Asahan Regency, Labuhan Batu Regency, Deli Serdang Regency, and Serdang Bedagai Regency. The total area of the coastal sub-district in the eastern part of North Sumatra is $43,133.44 \mathrm{~km} 2$, which consists of 35 coastal districts with a total of 436 villages. On the east coast of North Sumatera, there are only 6 (six) small islands. Since the area of the east coast of North Sumatra is along the Strait of Malacca, the potential for pollution of the marine environment is greater than the west coast.

Currently, Indonesia has several laws and regulations related to fishermen. Based on the findings of field research conducted in 2018 as the first phase, it was found that; (a) Regulations on the Protection of Fishermen in North Sumatra Province especially Medan City and Serdang Bedagai Regency still refer to the national regulation such as Presidential Decree Number 18/ 1978 concerning the ratification of International Convention On Civil Liability for Oil Pollution Damage, Law No. 17 of 1985 concerning ratification on United Nations Convention On The Law Of The Sea, Law No. 32 of 2014 concerning sea, Law No. 7 of 2016 concerning Protection and Empowerment of Fishermen, fish cultivators, and salt and candy farmers and other relevant national legislation. The government of North Sumatera Province faced challenges and obstacles to protect Fishermen's rights through the implementation of the laws as stated previously due to a lack of data and human resources support. (b) There is no provincial regulation of North Sumatra Province to protect Fishermen in the form of compensation for sea pollution caused by a sea accident. (c) Lack of 
coordination between government agencies, community, and fishermen associations. ${ }^{12}$

In this report, the fisherman through Himpunan Nelayana Seluruh Indonesia (HNSI)/Indonesian Union of Fishermen stated that the existence of the two regulations namely Law No. 7 of 2016 concerning Protection and Empowerment of Fishermen, Fish Cultivators, and Salt and Candy Farmers and Fisheries No. 71 of 2016 concerning Fish Placement and Fishing Equipment Placement are enough to ensure the fishermen to have income for daily life. ${ }^{13}$ In reality, the fishermen lose their income when there is pollution of the marine environment. For this situation, fishermen who became informants including HNSI of North Sumatra Province mentioned that they need special policies from the Province in the form of Regional Regulations and Governor Regulations related to the distribution of compensation funds to fishermen who are affected by pollution of the marine environment. It is important to realize legal certainty for the community and facilitate government work to provide compensation funds for fishermen affected by sea pollution. The wishes of these fishermen are in-line with the mandate of Law No. 23 of 2014 concerning local government. This law provides an explanation of the division of affairs in the field of maritime affairs and fisheries among the central, provincial, and district/city governments.

\begin{tabular}{|l|l|ll|}
\hline No & Sub-affairs & The Provincial government \\
\hline $\mathbf{1}$ & $\begin{array}{l}\text { Marine, Coastal } \\
\text { and Small } \\
\text { Islands }\end{array}$ & a. & $\begin{array}{l}\text { Management of marine space up to 12 } \\
\text { miles outside of oil and gas. }\end{array}$ \\
b. & $\begin{array}{l}\text { Issuance and utilization of ocean space } \\
\text { under 12 miles outside of oil and gas. }\end{array}$ \\
a. & $\begin{array}{l}\text { Empowerment of coastal communities } \\
\text { and small islands. }\end{array}$ \\
\hline
\end{tabular}

12 Suhaidi, Sutiarnoto and Syaiful Azam, "Perlindungan Hukum Nelayan Pantai Timur Sumatera Utara Berupa Ganti Rugi Terhadap Pencemaran Akibat Kecelakaan Kapal Tanker di Selat Malaka," (unpublished manuscript, 2018), Final Report.

13 Ibid. 


\begin{tabular}{|l|l|l|}
\hline 2 & $\begin{array}{l}\text { Capture } \\
\text { fisheries }\end{array}$ & $\begin{array}{l}\text { a. } \\
\text { banagement of fish and marine areas } \\
\text { up 12 miles. } \\
\text { Issuance of capture fisheries business } \\
\text { licenses for fishing vessels over 5 GT } \\
\text { to 30 GT. } \\
\text { Determination of construction sites } \\
\text { and management of provincial } \\
\text { fisheries ports. }\end{array}$ \\
\hline $\mathbf{3}$ & $\begin{array}{l}\text { Fisheries } \\
\text { Cultivation } \\
\text { Issuance of permits and fishing vessels } \\
\text { with sizes above 5 GT up to 30 GT. }\end{array}$ \\
\hline $\mathbf{4}$ & $\begin{array}{l}\text { Marine } \\
\text { Resources and } \\
\text { Fisheries } \\
\text { Supervision }\end{array}$ & $\begin{array}{l}\text { Issuance of IUP in the field of fish cultivation } \\
\text { whose business is across regency/city in 1 } \\
\text { (one) Province. }\end{array}$ \\
\hline $\mathbf{5}$ & $\begin{array}{l}\text { Marine resources and fisheries surveillance } \\
\text { up to 12 miles. } \\
\text { and Marketing }\end{array}$ & $\begin{array}{l}\text { Marketing business license issuance and } \\
\text { management of fishery products across the } \\
\text { district/city within 1 (one) Province. }\end{array}$ \\
\hline
\end{tabular}

Table 1. Affairs in the field of marine and fisheries in the Provincial Government according to Law No. 23 of 2014 concerning Local government

These national regulations have become the basis for the North Sumatra provincial government to ratify the North Sumatra Province Regulation No. 2 of 2017 concerning the Spatial Planning for the North Sumatra Province in 2017-2037. The existence of a Regional Regulation on the Provincial Spatial Plan (RTRWP) can be a reference to find out the legal regulatory needs of the community in their area including traditional fishing groups who earn their income from the sea.

There are some lessons learned from the research process conducted in North Sumatera and Riau Islands. First, if the traditional fishermen in North Sumatra have never had an experience related to compensation for sea pollution occurring in their fishing areas, 
fishermen in the Riau Islands province already have this experience. Based on interviews with the Riau Islands Province Environmental Office, it is known that the absence of regulations regarding pollution compensation for fishermen is circumvented by conducting media between the perpetrators of pollution and fishermen affected by sea pollution.

In 2017, the Riau Islands Province Environment and Forestry Service (DLHK) handled the problem of pollution of the marine environment involving the developer responsible for constructing the Busung Airport in Bintan Regency, Riau Islands Province. The dispute arises when the fishermen experience a drop in their income due to pollution of the marine environment caused by the development process of fishermen's floating buoys. In this situation, DLHK Riau Islands Province acts as an institution that provides information about the conditions of pollution that occur. After conducting research, DLHK of the Riau Islands Province ensured that there were four points of river flow that experienced pollution and empties into the floating areas of the fishermen. This information was conveyed by DLHK Riau Islands Province to Fishermen united under Himpunan Nelayan Seluruh Indonesia (HSNI), Fishermen Union of Indonesia.

Based on the information received from the informants, the process of calculating compensation has begun to be implemented and each party proposed how much loss they experienced. HNSI said that the losses suffered by floating kelong fishermen were 1.8 billion. ${ }^{14}$ This loss is calculated based on the loss of all the kelong and average daily income earned by fishermen. The calculation of losses carried out by fishermen is also based on the daily price of fish sold by fishermen to buyers or collectors. The method of calculating such losses has caused conflicts between the developers and fishermen. For this reason, the Riau Islands Province DLHK requested assistance from the Riau Islands Province Marine and Fisheries Service (DKP) to get involved. Technically, the involvement of the Riau Islands Province DKP was assisted by the Bintan Regency DKP. The calculation carried out by the DKP of the Riau Islands Province is based on the calculation of

14 A kelong (or kellong) is an offshore platform built predominantly with wood, which can be found in waters off Indonesia. Only a handful remain around Singapore due to rapid urbanisation. Kelongs are built by fishermen primarily for fishing or fish farming purposes, although larger structures can also function as dwellings for them and their families. 
losses of kelong-kelong and fish habitat, species of fish, and the price of fish on the market. The compensation calculation was finally successfully mediated by DLHK Riau Islands Province with a note that the calculation of compensation is highly dependent on the honesty of the fishermen. Compensation payments are made by the developer to fishermen who are affected by the pollution of the marine environment caused by the development process. ${ }^{15}$

Another situation in the Riau Islands province related to pollution of the marine environment caused by Tankers or vessels without collisions. Interviews with DLHK Riau Islands Province, which handles Hazardous and Toxic Waste Material management, revealed that, in 2019, DLHK Riau Islands Province had investigated tankers suspected of dumping waste in the Riau Islands Sea. The team that took samples at sea found that the samples were not waste but sediment. This has an impact on the release of tankers suspected of dumping waste into the sea because compensation can only be requested if the pollution was caused by ship oil spill. This condition has actually been long complained by fishermen who are living in the surrounding areas of the Riau Islands province. Today, Fishermen are only able to hope for assistance from the government to provide fishing nets to replace their property damaged by oil spills from former ships or tankers passing through the Riau Islands' waters. ${ }^{16}$

Referring to the situation and conditions above, it is obvious that both North Sumatra Province and Riau Islands Province face some challenges in legal protection for fishermen affected by sea pollution, especially in terms of compensation. First, the government did not have precise data regarding the amount of fishermen's earnings before or after pollution occurs. Secondly, the absence of a North Sumatra Province Regional Regulation in terms of legal protection for fishermen related to compensation for pollution of the marine environment sourced from oil spills to complicate for the community and government in law enforcement efforts. The existence of regulations and policies of the Government of the Province of North Sumatra and the Riau Islands in terms of compensation for pollution of the marine environment in the Malacca Strait is in line with the national

15 Interview to the informant, staff of (Regional agency for environment and forestry/DLHK) Riau Island Province on 3 August 2019.

16 Ibid. 
arrangements of the Indonesian State. Indonesia has ratified the 1982 Sea Law Convention with Law no. 17 of 1985 and the International Convention on Civil Liability for Oil Pollution Damage, 1969 (CLC 1969) through Presidential Decree (Keppres) RI No. 18 of 1978. A law that strengthens the provincial authority to manage marine resources in its territory, which is as far as 12 (twelve) nautical miles measured from the coastline towards the high seas and / or towards archipelagic waters, is regulated in Law No.32 of the 2014 concerning Local government.

\section{OPPORTUNITIES OF THE IMPLEMENTATION OF COMPENSATION FOR TRADITIONAL FISHERMEN AFFECTED BY SEA POLLUTION}

The study data reveal that in the coastal area of North Sumatra province, especially in the Coastal area of Bagan Deli, Medan, Belawan City and Serdang Bedagai Regency, fishermen experience marine pollution. According to their experience, most marine pollution is the result of waste from industries operating in the area around Kelurahan Bagan Deli, Medan. In addition, oil spills from PT. Pertamina Company which is located in Belawan Harbour also has worsened the level of water pollution. The fishermen can only let the water pollution continue even though it has harmed them in terms of catches because various marine animals and plants are wiped out from their habitat. This is certainly a result of the fishermen's ignorance regarding compensation arrangements related to the sea pollution that should have been reported to the government.

Furthermore, the fishermen feel the need for improvement in providing legal protection for east coast fishermen related to compensation for fishermen due to water pollution, namely the need for socialization and approaches from the government to the community regarding all regulations regarding compensation funds for fishermen who feel the impact of pollution water. There needs to be supervision from the local government relating to the implementation of these regulations in order to protect fishermen and provide a sense of fairness and comfort, the government should pay more attention to the needs of fishermen and not just side with the companies so that all fishermen feel protected their rights.

Subsequent data were collected from Kuala Lama Village, Pantai Cermin District, Serdang Bedagai. Most of the people who lived 
in the village work as traditional fishermen catching shrimp using small boats. They admitted that after 20 years being fishermen, they had never seen or known any sea pollution occurring in Serdang Bedagai. An interesting thing when the field research was conducted was the assumption of fishermen that the presence of ship traffic that does not cross the sea in the Serdang Regency is different. All ships pass through the outermost island, i.e., through Pulau Berhala, reducing any possibility of a collision between tankers that may result in sea pollution. Awareness of the possibility of tanker collision began to be realized when researchers conveyed information relating to the operation of the Port of Kuala Tanjung in Batu Bara Regency. The operation of this new port increases the likelihood of tanker ship collisions resulting in worse sea pollution as Kuala Tanjung Port is wider than Belawan Harbor.

The interview with the North Sumatra Provincial Environmental Agency (DLH/Dinas Lingkungan Hidup) revealed that there have been no tanker incidents in the North Sumatra Province. When sea pollution has an impact on fishermen, the North Sumatra Province's DLH will conduct the cleaning and will be the same as cleaning when the water is contaminated with the toxic hazardous material. The challenge for the protection of the affected fishermen is felt by the Provincial DLH as they still require more intensive coordination between the central and regional parties, especially related to compensation payments. In the past, pollution carried out in the tourism industry, which led to the payment of compensation by the perpetrators of the tourism industry, was subject to fines paid by the perpetrators to be sent into the central treasury not managed by the North Sumatra Province DLH. This situation aroused debate because the necessity to deposit fine funds to the central treasury was unclear and the bureaucracy was not good.

This situation shows that North Sumatera do not have experience yet in tanker accidents on one hand and lack of regulation on the protection of the traditional fishermen on the other hand can be an opportunity. It is an opportunity for the North Sumatera government to start to develop regulation with regard to protecting the traditional fishermen affected by sea pollution. The fact that tanker accidents in the waters of the North Sumatra Province has not been recorded yet gives sufficient time for the provincial government to conduct intensive studies to deal with pollution of the marine environment caused by the 
ship collision, including the management of funds paid as compensation for the pollution caused by pollution.

The case handled by DLHK in the Riau Islands Province regarding sea pollution which has caused compensation payments to kelong fishermen in Bintan Regency should be a good lesson for the DLH officials in North Sumatra Province. The important role of the Riau Islands DKP may be a lesson for the North Sumatra Province DKP in calculating compensation for fishermen. The results of a study in $2018^{17}$ stated that the North Sumatra Province DKP was oriented to its duties, principal and function, namely as the office responsible for the welfare of the fishermen. When sea pollution occurs, according to the North Sumatra Province DKP, the Office with the most authority, in this case, is the North Sumatra Province DLH. The experience of the Riau Islands Province DLHK in collaboration with the Riau Islands Province DKP and the Bintan Regency DKP should be an opportunity to maximize the achievement of the North Sumatra Province DKP vision for the welfare of fishermen. The North Sumatera Province government could coordinate with the Riau Islands Province DLHK and the Riau Islands Province DKP to collect information on how the Riau Islands government could protect traditional fishermen by providing compensation when sea pollution occurs in their area. The North Sumatera Government should learn that no conflict arose when the Riau Islands Province DLH facilitated the mediation between the actor of pollution and the traditional fishermen.

As stated previously, the absence of a tanker collision in the present record provides sufficient time for the two parties in charge, the DLH and DKP in the North Sumatera province, to jointly arrange for compensation for the fishermen should they be affected by sea pollution. This arrangement can be carried out in line with the program to provide life insurance for fishermen who are at high risk for their safety while fishing at sea. The program provides 200 million insurance for the families left by fishermen who are drowning in the sea and other types of insurance in accordance with Law No. 16 Regarding Fishermen Protection.

17 Suhaidi, Sutiarnoto and Syaiful Azam, "Perlindungan Hukum Nelayan Pantai Timur Sumatera Utara Berupa Ganti Rugi Terhadap Pencemaran Akibat Kecelakaan Kapal Tanker di Selat Malaka," (unpublished manuscript, 2018), Final Report. 
This research findings shows the opportunities in the regulation of the protection of fishermen affected by pollution of the marine environment are pollution prevention programs. PT Pelabuhan Indonesia I-Pelindo 1 mentioned it currently has a special division on environmental management. The Environmental Management Unit as a technical division of PT Pelabuhan Indonesia I-Pelindo 1 has a special duty to prevent sea, air, and land pollution from occurring. The Environmental Management Unit periodically collects water samples at the Port for inspection in the laboratory of the AMDAL section of the North Sumatra Province government.

Another program undertaken by PT Pelabuhan Indonesia IPelindo 1 is the enforcement of Standard Operational Procedures (SOPs) to secure environmental pollution that may occur in the Port area. Currently, the informant mentioned that PT Pelabuhan Indonesia I-Pelindo 1 plans to develop a green and eco port management program. The program is almost the same as Port management in Batam, Riau Islands province. The interesting thing part about the green-eco port program is the rejuvenation program for tools used in the port area, thereby reducing pollutants and developing a port area environmental management system. This environmental management system is interested in managing goods loading and unloading hours to reduce the emissions of fuel oil (BBM) produced by port machinery.

\section{CONCLUSIONS AND RECOMMENDATION}

The efforts in protecting and compensating fishermen from marine environment pollution are subject to several challenges. First, the increased risk of marine pollution is due to the presence of two ports Belawan and Tanjung Gading. The existence of these two ports provides a challenge for the North Sumatra provincial government in the management of marine ecosystems, given the increasingly crowded sea traffic in the form of passing and or anchoring of tankers within Indonesia through the Straits of Malacca. Secondly, there are regulations concerning the protection of fishermen to guarantee the acquisition of fishing but it is not effectively applicable as there are no regulations relating to sea pollution caused by collisions of tankers that cause fishermen to not be able to fishing in uncertain time period.

In every challenge there are always opportunities for better marine management. Firstly, the absence of any tanker accident in the 
waters of the North Sumatra province gives enough time for the local government to conduct a study related to protection of fishermen in the form of compensation, including the management of compensation for the pollution. As a consequence, there will be time to develop a regulation that deals with such a situation. Secondly, there is a development program that aims to reduce pollution occurring in the seaport area, namely the green-eco port and the port area environmental management system.

This study recommends that the government learn from crosssectoral experience, especially if related to parties like the DLH, DKP, and Port management in handling pollution. Furthermore, the government is advised to draft the relevant regulations addressing the issue of compensation for traditional fishermen affected by the pollution of the marine environment.

\section{ACKNOWLEDGMENT}

We would like to thank the Research and Service Institute of Direktorat Jenderal Penguatan Riset dan Pengembangan Kemenristekdikti who supported the authors to implement research program through DRPM research scheme of the 2019 Fiscal Year based on the Agreement Letter Number: 11/E1/KP.PTNBH/ 2019, March $29^{\text {th }} 2019$. 